\title{
Knowledge and attitudes of nursing students about pain management
}

\author{
Hemşirelik öğrencilerinin ağrı yönetimi ile ilgili bilgi ve tutumları
}

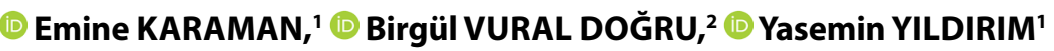

\begin{abstract}
Summary
Objectives: The purpose of the present study was to examine the knowledge and attitudes of Turkish nursing students about pain management.

Methods: The participants in this cross-sectional study were 190 nursing students who were studying at a nursing faculty in western Turkey. The research data were collected between March and June of the academic year 2015-2016, using a Student Description Form and the Nurses' Knowledge and Attitudes Survey Regarding Pain (NKASRP).

Results: The mean age of the students in the study sample was $23.06 \pm 1.44$ years. In all, $83.7 \%$ were female, $96.8 \%$ were unmarried, $94.7 \%$ were working as a nurse, and all had social security. The mean score of the NKASRP was $15.85 \pm 3.25 \%$. A comparison of the knowledge scores with student characteristics revealed that only the status of current employment as a nurse demonstrated a significant difference. No significant difference was detected between the NKASRP score and variables such as age and the score of the worst pain ever experienced ( $p>0.05)$.

Conclusion: It was determined that the students had a generally poor level of pain knowledge. It will improve the quality of life of patients if pain management is given a greater place in undergraduate education.

Keywords: Attitude; nursing; pain; pain management; student.

Özet

Amaç: Bu çalışmanın amacı intörn öğrencilerin ağrıya yönelik bilgi düzeylerini değerlendirmektir.

Gereç ve Yöntem: Kesitsel tipteki bu çalışma örneklemini Türkiye'nin batısında öğrenim gören 190 hemşirelik fakültesi öğrencisi oluşturmuştur. Araştırma verileri, 2015-2016 yılı Mart-Haziran ayları arasında, "Öğrenci Tanıtım Formu ve Hemşirenin Ağrı ile Illgili Bilgi ve Tutum Anketi (NKASRP)" kullanarak toplanmıştır.

Bulgular: Çalışma örneklemini oluşturan öğrencilerin yaş ortalaması 23.06 \pm 1.44 olup; \%83.7'si kadın, \%96.8'i bekar, \%.5.3'ü hemşire olarak çalışmakta ve öğrencilerin tamamının sosyal güvencesi bulunmaktadır. Öğrencilerin NKASRP toplam puan

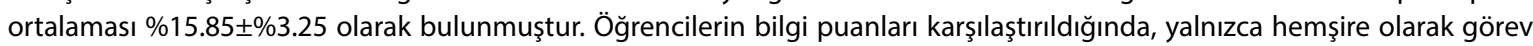
yapanlarda anlamlı fark olduğu bulunmuştur. Yaş ve şimdiye kadar yaşanan en kötü ağrı skoru gibi değişkenler ile NKASRP arasında anlamlı bir fark bulunmamıştır ( $p>0.05$ ).

Sonuç: Öğrencilerin ağıı bilgi puanlarının düşük olduğu görülmüştür. Lisans eğitiminde ağrı yönetimine daha fazla yer verilmesinin hastaların yaşam kalitesini yükseltmeye yardımcı olacağı düşünülmektedir.
\end{abstract}

Anahtar sözcükler: Tutum; hemşirelik; ağrl; ağıı yönetimi; tutum; öğrenci.

\section{Introduction}

Pain is an unpleasant sensation experienced by both sick and healthy people. The pain which can be experienced for various etiological reasons is among the primary symptoms of many health problems. ${ }^{[1]}$ Pain has an adverse effect on a person's social life, physical, mental condition, and quality of life..$^{[2,3]}$ In addition, pain causes longer stays in hospital, and increases morbidity and mortality. ${ }^{[4]}$

Effective treatment of pain is important in raising a person's quality of life and providing comfort, for effective treatment it is essential to assess pain correctly. ${ }^{[2,3]}$ However, considering that individual

'Department of Medical Nursing, Ege University Faculty of Nursing, İzmir, Turkey

${ }^{2}$ Mersin University Faculty of Nursing, Mersin, Turkey

Submitted (Başvuru tarihi) 14.12.2017 Accepted after revision (Düzeltme sonrası kabul tarihi) 12.11.2018 Available online date (Online yayımlanma tarihi) 20.11.2018

Correspondence: Emine Karaman. Ege Üniversitesi Hemşirelik Fakültesi, Bornova, İzmir, Turkey.

Phone: +90 - 232 - 3885620 e-mail: emine.karaman@ege.edu.tr

(c) 2019 Turkish Society of Algology 
characteristics can affect the perception of pain, it is difficult to assess pain objectively. Today, pain is routinely assessed as the fifth vital finding.

An important responsibility of healthcare professionals is to eliminate pain. ${ }^{[5]}$ As part of the healthcare team, nurses play a major role in effective pain management. It has been stated that nurses must be sensitive to pain and have adequate knowledge of it. $^{[6]}$ The American Pain Society has also stated that pain is not the responsibility of the patient, but that when a patient expresses pain, pain management is the responsibility of the nurse. ${ }^{[7]}$ Studies have shown that nurses' knowledge of pain, pain assessment and management is inadequate, that their knowledge generally derives from their university education. ${ }^{[8-14]}$ Results of studies conducted with nursing students show similar results to studies carried out with nurses. It has been shown that student nurses' knowledge of the identification, assessment of pain and of pain control is at a medium or inadequate level. ${ }^{[10,13-18]}$

It is clear that the knowledge of pain management of health personnel and especially of nurses evaluating pain is important in the effective management of pain. In order to strengthen the knowledge of pain of nurses as nursing trainers at this point, it is necessary to structure their degree education based on a firm foundation. By the time that students complete their university education, they should have acquired comprehensive knowledge on the topic of pain and pain management. ${ }^{[19]}$ Finally, it is thought that determination of students' levels of knowledge of pain and its management can be the key to remedying deficiencies in that area. The purpose of the present study was to evaluate the level of knowledge and attitudes regarding pain management among nursing students in Turkey.

\section{Materials and Methods}

\section{Ethical considerations}

The study was approved by the institutional review board (IRB) of Ege University Nursing Faculty (IRB No 2016-128). Information was given to all students concerning the objectives of the study, and their oral approval was obtained.

\section{Study design}

This was a descriptive cross-sectional study.

\section{Participant and data collection}

In this study, sampling was not used and the research population included all of the students. The inclusion criteria were being a student of the nursing faculty and volunteering to participate in the study. The study population consisted of 257 students, of whom 190 participated in the study, 32 did not agree to participate and 35 did not fully complete the questionnaire.

It was conducted between March and June 2016 at a nursing faculty providing degree-level education in the west of Turkey. Only intern students of the faculty were included in the study. The school of nursing grants nursing degrees after four years of education. In the first three years at this nursing faculty, time is divided equally between theory classes and practice, while in the final year integrated education is provided with emphasis on practice in the form of an internship system. At the end of their four years of education the students graduate with a bachelor's degree.

\section{Instruments}

The study data were collected using a Student Description Form and the Nurses' Knowledge and Attitudes Survey Regarding Pain (NKASRP).

The student description form: This form consisted of 13 questions to specify the students' socio-demographic, educational characteristics and individual experiences of pain.

Nurses' Knowledge and Attitudes Survey Regarding Pain Scale (NKASRP): The NKASRP scale assesses nurses' knowledge and attitudes regarding pain management. There are questions on the scale about attitudes to pain management, pharmacological and non-pharmacological approaches. Of the 39 questions on the scale, 22 have true/false answers, 13 are multiple choice, and there are two questions on each of two case studies. ${ }^{[5,12]}$ Each true/false answer on the NKASRP was calculated as a percentage. Each correct answer scored 1 point, while an incorrect or unanswered question scored 0 . The total score varied between 0 and 39. Correct answer rates were calculated by dividing the total number of correctly answered items by the total number of items. The NKASRP was developed by Ferrell, McGuire, and Donovan in 1993. The validity and reliability study 
of the NKASRP for Turkish society was conducted by Yildirim et al. ${ }^{[12]}$ It is considered to be reliable (Cronbach's $a=0.74$ ).

\section{Statistical analysis}

The program SPSS 21.0 was used for the data analysis. Kolmogorov-Smirnov analysis was used to determine the conformity of the data to normal distribution. The variables were evaluated as means, percentages, frequencies and standard deviations. $T$ test and Spearman correlation analysis were used in evaluating the data. The results were considered significant when the P-value was less than 0.05 .

\section{Results}

A total of 190 Bachelor of Science nursing students completed the questionnaires. Table 1 shows data relating to the students' socio-demographic characteristics and their personal experience of pain. The mean age of the participants was $23.06 \pm 1.44$ years. Most students (83.7\%) were female, $96.8 \%$ were unmarried, $5.3 \%$ were working as nurses, and all had social security. It was found that $28.4 \%$ of the students smoked, and $24.7 \%$ drank alcohol.

It was found that $84.7 \%$ of the students had no health problems, and that $88.4 \%$ were not regularly using any medication. The mean score for the worst pain that they had ever experienced was $7.35 \pm 1.73$, and they dealt with pain with analgesics, sleep and rest $(82.6 \%, 47.4 \%, 46.3 \%$ respectively). It was found that $81.6 \%$ of the students had a relative, or a patient whose care they had been responsible for, who had experienced severe pain. Also, $73.7 \%$ of the students thought that they had an adequate level of knowledge in coping with pain (Table 1). The average correct response rate was $40.64 \%$, ranging from $17.94 \%$ to $61.53 \%$. Out of the 39 pain knowledge questions assessed, the mean number of correctly answered questions was 15.85 \pm 3.25 (7.0-24.0) (Table 1).

Table 2 shows the percentages of correct and wrong answers for each item on the questionnaire. It can be seen that the highest proportion of correct responses was on item 19, "After the initial recommended dose of opioid analgesic, subsequent doses are adjusted in accordance with the individual patient's response", and the lowest proportion of correct responses was on item 35 , relating to narcotic and opi-
Table 1. Socio-demographic and professional characteristics of students

\begin{tabular}{lcc}
\hline Characteristic & n & $\%$ \\
\hline Gender & & \\
$\quad$ Female & 159 & 83.7 \\
$\quad$ Male & 31 & 16.3 \\
Marital status & & \\
$\quad$ Married & 6 & 3.2 \\
$\quad$ Unmarried & &
\end{tabular}

The status of currently

working as a nurse

$\begin{array}{lcc}\text { Yes } & 10 & 5.3 \\ \text { No } & 180 & 94.7 \\ \text { Social security } & & \\ \text { Yes } & 190 & 100.0 \\ \text { No } & 0 & 0.0\end{array}$

Any health problem

$\begin{array}{lcc}\text { Yes } & 29 & 15.3 \\ & 161 & 84.7\end{array}$

Regularly use medication

$\begin{array}{lll}\text { Yes } & 22 & 11.6\end{array}$

$\begin{array}{lll}\text { No } & 168 & 88.4\end{array}$

Methods of coping with pain*

$\begin{array}{lll}\text { Analgesics } & 157 & 82.6\end{array}$

Sleep $\quad 90 \quad 47.4$

Massage $\quad 53 \quad 27.9$

Warm application $\quad 53 \quad 27.9$

Cold application $\quad 29 \quad 15.3$

$\begin{array}{lll}\text { Rest } & 88 & 46.3\end{array}$

Herbal products $\quad 13 \quad 6.8$

$\begin{array}{lll}\text { Others } & 3 & 1.6\end{array}$

Smoking $\quad 54 \quad 28.4$

Drink alcohol $\quad 47 \quad 24.7$

The experience of pain in their

relatives or patients

$\begin{array}{lll}\text { Yes } & 155 & 81.6\end{array}$

No $\quad 35 \quad 18.4$

Finding adequate level of knowledge in coping with pain

$\begin{array}{lcc}\text { Yes } & 140 & 73.7 \\ \text { No } & 50 & 26.3\end{array}$

\begin{tabular}{lc}
\hline & $\begin{array}{c}\text { Mean } \pm \text { SD } \\
\text { (min.-max.) }\end{array}$ \\
\hline Age & $\begin{array}{c}23.06 \pm 1.44 \\
(21-36)\end{array}$ \\
$\begin{array}{l}\text { The score of the worst pain } \\
\text { experienced until now }\end{array}$ & $7.35 \pm 1.73$ \\
The mean scores of NKASRP & $15.85 \pm 3.25$ \\
\hline
\end{tabular}

SD: Standart deviation; min: Minimum; max: Maximum. 
Table 2. The percentages of correctly answered items in the questionnaire

\begin{tabular}{|c|c|c|}
\hline $\begin{array}{l}\text { Item } \\
\text { no }\end{array}$ & Item content (correct answer) & $\begin{array}{c}\text { Corrrect } \\
\text { responses }\end{array}$ \\
\hline
\end{tabular}

\section{True or false questions}

1

Observable changes in vital signs must be relied upon to verify a patient's statement that he has severe pain. (False)

Because of an underdeveloped neurological system, children under 2 years of age have decreased pain sensitivity and limited memory of painful experiences. (False)

Patients may sleep in spite of severe pain. (True)

Comparable stimuli in different people produce the same intensity of pain. (False)

Aspirin and other non-steroidal anti-inflammatory agents are NOT effective analgesics for bone pain caused by metastases. (False)

Non-drug interventions (e.g., heat, music, image) are very effective for mild to moderate pain control but are rarely helpful for more severe pain. (False)

Respiratory depression rarely occurs in patients who have been receiving opioids over a period of months. (True)

Aspirin $650 \mathrm{mg} P O$ is approximately equal in analgesic effect to meperidine (Demerol) 50mg PO. (True)

The World Health Organization (WHO) pain ladder suggests using single analgesic agents rather than combining classes of drugs (e.g. combining an opioid with a nonsteroidal agent). (False)

The usual duration of action of meperidine (Demerol) IM is 4-5h. (False)

Research shows that promethazine (Phenergan) is a reliable potentiator of opioid analgesics. (False)

Patients with a history of substance abuse should not be given opioids for pain because they are at high risk for repeated addiction. (False)

Beyond a certain dosage of morphine increases in dosage will not increase pain relief. (False)

The patient with pain should be encouraged to endure as much pain as possible before resorting to a pain relief measure. (False)

Based on one's religious beliefs a patient may think that pain and suffering is necessary. (True)

After the initial recommended dose of opioid analgesic, subsequent doses are adjusted in accordance with the individual patient's response. (True)

Giving patients sterile water by injection (placebo) is often a useful test to determine if the pain is real. (False)

\section{Multiple choice questions}

The recommended route of administration of opioid analgesics to patients with prolonged cancer-related pain is: (oral)

The recommended route of administration of opioid analgesics to patients with brief severe pain of sudden onset, e.g. trauma or postoperative pain, is: (intravenous) 
Table 2. The percentages of correctly answered items in the questionnaire (cont.)

\begin{tabular}{lrr}
\hline Item & Item content (correct answer) & Corrrect \\
no & responses \\
\cline { 2 - 2 } & n & $\%$
\end{tabular}

Which of the following IV doses of morphine administered over a $4 \mathrm{~h}$ period would be equivalent to $30 \mathrm{mg}$ of oral morphine given q4 h: (morphine $10 \mathrm{mg} \mathrm{IV}$ )

Analgesics for post-operative pain should initially be given: (around the clock on a fixed schedule)

A patient with chronic cancer pain has been receiving daily opioid analgesics for 2 months. The dose increased during this time period. Yesterday the patient was receiving morphine $200 \mathrm{mg} / \mathrm{h}$ intravenously. Today he has been receiving $250 \mathrm{mg} / \mathrm{h}$ intravenously for $3 \mathrm{~h}$. The likelihood of the patient developing clinically significant respiratory depression is: (less than $1 \%$ ) The most likely explanation for why a patient with pain would request increased doses of pain medication is: ( The patient is experiencing increased pain) caring for patients in pain: (Patients should be individually assessed to determine cultural influences on pain)

What do you think is the percentage of patient who over report the amount of pain they have? Circle the correct answer. (0)

Narcotic/opioid addiction is defined as psychological dependence accompanied by overwhelming concern with obtaining and using narcotics for psychic effect, not for medical reasons. It may occur with or without the physiological changes of tolerance to analgesia and physical dependence (withdrawal). Using this definition, how likely is it that opioid addiction will occur as a result if treating pain with opioid analgesics? Circle the number closest to what you consider the correct answer. $(<(1-5 \%))$

\section{Case studies}

36 Patient A: Andrew is 25 years old and this is his first day following abdominal surgery. As you enter his room, he smiles at you and continues talking and joking with his visitor. Your assessment reveals the following information: $\mathrm{BP}=120 / 80 ; \mathrm{HR}=80 ; \mathrm{R}=18$; on a scale of 0 to $10(0=$ no pain/discomfort, $10=$ worst pain/discomfort $)$ he rates his pain as 8 . A. On the patient's record you must mark his pain on the scale below. Circle the number that represents your assessment of Andrew's pain. (8)

Your assessment, above, is made $2 \mathrm{~h}$ after he received morphine $2 \mathrm{mg}$ IV. Half hourly pain ratings following the injection ranged from 6 to 8 and he had no clinically significant respiratory depression, sedation, or other untoward side effects. He has identified 2 as an acceptable level of pain relief. His physician's order for analgesia is "morphine IV 1-3mg q1 h PRN pain relief". Check the action you will take at this time. (Administer morphine 3mg IV now)

Patient B : Robert is 25 years old and this is his first day following abdominal surgery. As you enter his room, he is lying quietly in bed and grimaces as he turns in bed. Your assessment reveals the following information: $B P=120 / 80 ; H R=80 ; R=18$; on a scale of 0 to $10(0=$ no pain/discomfort, $10=$ worst pain/discomfort $)$ he rates his pain as 8 . A. On the patient's record you must mark his pain on the scale below. Circle the number that represents your assessment of Robert's pain: (8)

Your assessment, above, is made two hours after he received morphine $2 \mathrm{mg}$ IV. Half hourly pain ratings following the injection ranged from 6 to 8 and he had no clinically significant respiratory depression, sedation, or other untoward side effects. He has identified 2 as an acceptable level of pain relief. His physician's order for analgesia is "morphine IV 1-3mg q1 h PRN pain relief". Check the action you will take at this time: (Administer morphine 3mg IV now) 
Table 3. Relationship between students' pain knowledge score and some characteristics

\begin{tabular}{|c|c|c|c|c|}
\hline & $\mathbf{n}$ & Mean \pm SD & $\mathbf{t}$ & $\mathbf{p}$ \\
\hline \multicolumn{5}{|l|}{ Gender } \\
\hline Female & 159 & $16.11 \pm 3.21$ & 2.54 & .012 \\
\hline Male & 31 & $14.51 \pm 3.19$ & & \\
\hline \multicolumn{5}{|l|}{ Marital status } \\
\hline Married & 6 & $16.66 \pm 3.20$ & 617 & .538 \\
\hline Unmarried & 184 & $15.83 \pm 3.26$ & & \\
\hline \multicolumn{5}{|c|}{ The status of currently working as a nurse } \\
\hline Yes & 10 & $18.70 \pm 3.36$ & -2.291 & .004 \\
\hline No & 180 & $15.70 \pm 3.18$ & & \\
\hline \multicolumn{5}{|c|}{ Any health problem } \\
\hline Yes & 29 & $15.65 \pm 3.47$ & .363 & .717 \\
\hline No & 161 & $15.89 \pm 3.22$ & & \\
\hline \multicolumn{5}{|c|}{ Regularly use medication } \\
\hline Yes & 22 & 16.04.340 & -.287 & .775 \\
\hline No & 168 & $15.83 \pm 3.24$ & & \\
\hline \multicolumn{5}{|c|}{ The experience of pain in their relatives or patients } \\
\hline Yes & 155 & $15.90 \pm 3.32$ & -.460 & .646 \\
\hline No & 35 & $15.62 \pm 2.97$ & & \\
\hline \multicolumn{5}{|c|}{ Finding adequate level of knowledge in coping with pain } \\
\hline Yes & 140 & $15.72 \pm 3.33$ & .967 & .335 \\
\hline No & 50 & $16.24 \pm 3.00$ & & \\
\hline
\end{tabular}

SD: Standart deviation.

Table 4. The correlation between the mean values of the NKASRP and some characteristics

\begin{tabular}{lcc}
\hline Characteristics & \multicolumn{2}{c}{ NKASRP } \\
\cline { 2 - 3 } & $\mathbf{r}$ & $\mathbf{p}$ \\
\hline Age $^{*}$ & -.103 & .159 \\
$\begin{array}{l}\text { The score of the worst pain } \\
\text { experienceduntil now* }\end{array}$ & & \\
\hline
\end{tabular}

*Non normal distribution, Spearman correlation analysis.

oid agents (Table 2). Comparing the students' scores on knowledge of pain and their characteristics, a significant difference was found only with whether they were currently working as nurses (Table 3 ).

The relationship between the mean scores of the NKASRP and some characteristics is presented in Table 4. As shown, no significant difference was detected between the NKASRP and variables such as age, the score of the worst pain they had ever experienced $(p>0.05)$.

\section{Discussion}

It is well known that the knowledge, behaviour and attitudes of the health team, especially of nurses, are important for pain control when they are performing treatment. ${ }^{[6,7]}$ The American Pain Society has emphasised the role of nurses especially in pain control. ${ }^{[7]}$

This study provides important information about the level of pain knowledge among nursing students in Turkey. The findings showed that Turkish nursing students have poor knowledge and attitudes concerning pain management. It was seen that the students in our study did not give the correct answers to basic questions on pain. These findings are consistent with past studies and the results are concerning. The literature shows us that it was seen that the knowledge levels of both nurses and nursing students regarding pain were inadequate. ${ }^{[8-11,13,15-20]}$ Effective pain management depends on solid foundations such as physiopathological and pharmacological/nonpharmacological knowledge levels concerning pain. In spite of many changes and improvements in nurs- 
ing, pain management, reliable pain management has not yet been achieved for patients.

In a study by Yorulmaz and Aygun, most students stated that their own knowledge levels regarding pain were at a medium level, and in our study most students (73.7\%) thought that their level of knowledge of coping with pain was adequate. ${ }^{[14]}$ However, when students' knowledge levels were examined, it was seen that only $15.85 \pm 3.25$ of the 39 questions in our study were answered correctly. Thus it was clear that students did not have the knowledge to be able to manage pain adequately. In another study performed with nursing students, it was seen that students' mean pain scores were greater than in our study. ${ }^{[20]}$ We think that this difference arises from the greater number of working students in that study. This is because the mean scores of working students were statistically significantly higher than those of students who were not working.

It was found that $80.5 \%$ of the students in our study knew that patients themselves were best able to express their pain. Therefore, it was surprising to see that the students in the study did not take into account in a general sense patients' statements on pain scores in the case studies. It is thought that the reason for this is related to the students being affected by the body language of the patients indicating that they were cheerful when they were relating their pain. In the other case study in which the patient profile was similar, most students indicated the patient's pain as it had been stated, because the patient's body language was unhappy. This result also supports our view that students are affected by a patient's body language. Also, it was seen that students ignored the fact that pain is subjective and a person's responses to pain may be individual. This finding is consistent with previous findings. ${ }^{[16]}$

In pain management, the first step is to correctly determine the pain. It was seen that in this study approximately half of the students wrongly indicated the pain level in the case studies on the visual pain scale. At this point it was concluded that the step of correctly determining and assessing pain, which forms the basis of the approach to pain, had not been completely understood. These results were similar to the results of studies in the literature. In a study by Salatera et al. it was found that a small section of the students knew only the Visual Analog Scale from among the scales used in the assessment of pain. ${ }^{[17]}$ In a study conducted with nurses it was also found that $88.1 \%$ of the nurses did not use a scale in identifying pain, and only $26 \%$ asked patients how much pain they had. ${ }^{[13]}$

Lack of knowledge in major areas regarding medications was also a concern in this research. The correct assessment of pain is as important as correct treatment. There are various pharmacological and non-pharmacological methods with regard to pain. The World Health Organization recommends ladder treatment for pain. ${ }^{[21]}$ In addition, it has been found that non-pharmacological methods used in the management of pain should be integrated into treatment. In our study, it was found that the students used pharmacological treatment to alleviate pain at a rate of $82.6 \%$, approximately half of them chose methods like sleep, rest and massage as nonpharmacological methods. Although the students chose to use analgesics as easy and practical in managing pain, it was found that their knowledge of pharmacological pain management especially of opioid analgesics was low. The most commonly incorrect items were mainly related to knowledge of pain medications and administration. This study shows that students' knowledge of the actions of analgesics, their side effects, tolerance and dependence related to the clinical use of analgesic drugs is poor. These findings were similar to those of studies in the literature..$^{[8,9,11,19-21]}$ It is clear that the knowledge of pain, its management of both nurses and students is inadequate. Studies which have examined the pain experienced by patients support this result. In a study by the Turkish Pharmacists' Association and the Turkish Pain Association it was seen that $63 \%$ of people in Turkey suffer pain. In a situation where the knowledge levels of health personnel with regard to pain are inadequate, it is to be expected that patients will experience pain that pain will not be effectively managed. Here, education on pain comes to mind. All of the students in our study had had training on pain as part of their high school education programmes. However, it was established that there were still gaps in their knowledge of pain and pain management. In studies in the literature also, it was seen that the education of nurses on pain man- 
agement generally came from their degrees courses. [14, 22] Experts have determined that for the effective management of pain, it is necessary for the education of health team members before graduation to be continuously supported by extra training and courses. ${ }^{[23]}$ The low proportion of nursing students who receive education outside the school, not holding training programmes on pain at regular intervals, not making students sufficiently aware of the importance of pain management in their degree classes may be reasons for the inadequate knowledge level.

When we examined the relationship between levels of pain knowledge in the students and socio-demographic variables, we found a significant correlation only between pain and their status as working as nurses. This suggests that nurses' in-service training can improve their pain knowledge, and in fact it was seen in other studies that nurses generally had received in-service training on pain. ${ }^{[13]}$ In another study it was seen that the knowledge levels of finalyear students was lower than that of lower classes. ${ }^{[24]}$ In our study, we did not carry out a comparison with lower classes, but it was determined that the pain scores of final year students were low. This may be related to not repeating education on pain given at the beginning of degree studies.

Finally, it is clear that education on pain management is important. In this study, it was determined that the knowledge levels of most nursing students on pain and its management is inadequate. However, nurses must be able to make an effective assessment of pain, to keep actual pain within "livable" boundaries by using suitable pharmacological and non-pharmacological methods. This is because pain management is known to improve the quality of life of patients. In the light of all of these findings, it is thought that the present study will provide help in determining the content of degree programmes for nursing students.

\section{Conflict-of-interest issues regarding the authorship or article: None declared.}

Peer-rewiew: Externally peer-reviewed.

\section{References}

1. Nadler SF. Nonpharmacologic management of pain. J Am Osteopath Assoc 2004;104(11 Suppl 8):S6-12.

2. Erdine S, Hamzaoglu O, Ozkan O, Balta E, Domac M.
The prevalence of pain among adults in Turkey. Agri 2001;13:22-30.

3. Koçoğlu D, Özdemir L. The relation between pain and pain beliefs and sociodemographic-economic characteristics in an adult population. Agri 2011;23(2):64-70.

4. Aslan FE, Badir A, Selimen D. How do intensive care nurses assess patients' pain? Nurs Crit Care 2003;8:62-7. [CrossRef]

5. Ferrell BR, McGuire DB, Donovan MI. Knowledge and beliefs regarding pain in a sample of nursing faculty. J Prof Nurs 1993;9(2):79-88. [CrossRef]

6. Brown MA. The role of nurses in pain and palliative care. $J$ Pain Palliat Care Pharmacother 2013;27(3):300-2. [CrossRef]

7. Portenoy RK, Mehta Z, Ahmed E. Cancer pain management: General principles and risk management for patients receiving opioids. UpToDate 2017:1-12.

8. Duke G, Haas BK, Yarbrough S, Northam S. Pain management knowledge and attitudes of baccalaureate nursing students and faculty. Pain Manag Nurs 2013;14(1):11-9.

9. Kwekkeboom KL, Bumpus M, Wanta B, Serlin RC. Oncology nurses' use of nondrug pain interventions in practice. J Pain Symptom Manage 2008;35(1):83-94. [CrossRef]

10. Er MR, Eroğlu M, Altınel EC, Altınel L. Hemodialysis and pain. Turk Neph Dial Transpl 2013;22:167-170. [CrossRef]

11. Sayın S, Öztekin SD. Knowledge and Interventions of Postoperative Pain Management by Nurses in Surgical Wards at University and Tertiary State-Care Hospitals: İstanbul Survey. Turkiye Klinikleri J Surg Nurs-Special Topics 2015;1(3):23-29.

12. Yildirim YK, Cicek F, Uyar M. Knowledge and attitudes of Turkish oncology nurses about cancer pain management. Pain Manag Nurs 2008;9(1):17-25. [CrossRef]

13. Akdag R. Related to pain management nurses evaluation of knowledge, attitudes and clinical decision making status. [Master Thesis]. Gaziantep: Gaziantep University; 2008.

14. Yorulmaz G, Aygun M. Nursing students evaluation of pain related knowledge, [Master Thesis]. Istanbul: Istanbul Science of University; 2012.

15. Chiang LC, Chen HJ, Huang L. Student nurses' knowledge, attitudes, and self-efficacy of children's pain management: evaluation of an education program in Taiwan. J Pain Symptom Manage 2006;32(1):82-9. [CrossRef]

16. Chuk P. Determining the accuracy of pain assessment of senior student nurses: a clinical vignette approach. Nurse Educ Today 2002;22(5):393-400. [CrossRef]

17. Salanterä S, Lauri S, Salmi TT, Aantaa R. Nursing activities and outcomes of care in the assessment, management, and documentation of children's pain. J Pediatr Nurs 1999;14(6):408-15. [CrossRef]

18. Rahimi-Madiseh $M$, Tavakol M, Dennick R. A quantitative study of Iranian nursing students' knowledge and attitudes towards pain: implication for education. Int J Nurs Pract 2010;16(5):478-83. [CrossRef]

19. Al-Khawaldeh OA, Al-Hussami M, Darawad M. Knowledge and attitudes regarding pain management among Jordanian nursing students. Nurse Educ Today 2013;33(4):339-45. 
20. Plaisance L, Logan C. Nursing students' knowledge and attitudes regarding pain. Pain Manag Nurs 2006;7(4):167-75.

21. Goodrich C. Students' and faculty members' knowledge and attitudes regarding pain management: a descriptive survey. J Nurs Educ 2006;45(3):140-2.

22. Ozer S, Akyürek B, Başbakkal Z. Investigation of nurses' pain related knowledge, attitude and clinical decision making skills. Agri 2006;18(4):36-43.

23. Pöyhiä $R$, Kalso E. Pain related undergraduate teaching in medical faculties in Finland. Pain 1999;79(2-3):121-5. [CrossRef]

24. Laprise J. Identification of student nurses' knowledge and attitudes regarding pediatric pain management. Available at: https://opencommons.uconn.edu/usp_projects/28/. Accessed April 06, 2019. 